\title{
ARTWORK BY PAPAL SILVERSMITH FRANCESCO SPAGNA FOR ZAGREB CATHEDRAL: RELIQUARY BUST OF ST STEPHEN THE KING
}

\author{
Daniel Premerl
}

\author{
D. Premerl \\ Institute of Art History \\ Ulica grada Vukovara 68 \\ HR-10000 Zagreb \\ dpremerl@ipu.hr
}

\begin{abstract}
On the basis of archival documents from the Biblioteca Apostolica Vaticana the article reveals the silversmith Francesco Spagna as the master of the Zagreb reliquary bust of St Stephen the King (1635) commissioned by Francesco Barberini. The author summarizes previous research on the reliquary, comments the documents, and offers information about the silversmith Francesco Spagna and his works.
\end{abstract}

Key words: Francesco Spagna, reliquary bust of St Stephen the King, Zagreb cathedral, Francesco Barberini, Ivan Tomko Mrnavić, Alessandro Algardi, Gian Lorenzo Bernini

In 1635, cardinal Francesco Barberini - Urban VIII's vice-chancellor and nephew - made an extraordinary donation to Zagreb Cathedral: a reliquary bust of its titular saint, the eleventh-century Hungarian king Stephen (fig. 1-3). ${ }^{1}$ In the same year, Ivan Tomko Mrnavić - bishop of Bosnia and canon of Zagreb - referred to himself as the person who had brought Zagreb Cathedral's need for a new reliquary of its titular saint to the cardinal's attention, since the old one, as Mrnavic put it, had been melted down late in the previous century to pay off the soldiers of the Sisak fortress who had won against the Ottomans in 1593; upon hearing this the cardinal-nephew granted the request by donating the reliquary, which Mrnavić himself promptly took back to Zagreb. ${ }^{2}$

The Zagreb reliquary is a highly accomplished work of Roman Baroque metal sculpture and silversmith craft. $^{3}$ It remains one of the few surviving Roman $17^{\text {th }}$-century reliquary busts; also, one

\footnotetext{
${ }^{1}$ The cartouche on the plinth reads: SACRO/D · STEPHANI/VNGAR REGIS. APLIQ/CRANIO. IN ZAGABRIENSI/ ECCLIA. EIDEM DICATA. SERVATO/DECENTIVS ADSERVANDO/FRACISCVS TT S · LAVREN: IN DAMASO/S . $R \cdot$ E VICECANCELARIVS/DIACONVS CARDINALIS BARBERINVS/PIA IN S · REGEM OBSERVATIA/HVMILITER OFFERT/ANNO DNI MDCXXXV.

${ }^{2}$ IOANNES TOMCUS MARNAVITIUS, Pro Sacris Ecclesiarvm Ornamentis et Donariis. Contra eorum detractores, Roma, 1635, pp. 74-75. (...) dum Eminentissimus Princeps Franciscus Cardinalis Barberinus, incertum erga decorem domus Dei, an pauperum necessitates, indefessa munificentia, intra, extraque Urbem, per remotissima terrarum spacia, magis effusus, \& sanctae prodigus, ut potè SANTISSIMI URBANI PATRUI SUI, CUIUS PIA MUNIFICENTIA PASSIM FELICITER SACRA TECTA RESURGUNT, CUIUS PRETIOSIS DONARIIS OMNIA TEMPLA REFULGENT, CUIUS BENIGNA PROVIDENTIA AEVO NOSTRO IGNORATUR EGESTAS, si qua in alia Heroica virtute, in effusione paternorum viscerum sedulus imitator; ubi primum nuditatem Reliquiae Sanctissimi Regis, erga cuius cultum exardescit perpetuo, nuper à me accepit, pretiosissimum ornamentum, auro, argento, gemmisque ditissimum, ipsum Apostolici Regis caput, humeros, e pectus, exprimens, Ungarico Regali paludamento insigne, Regia Corona, ad imitationem Angelicae, Apostolicaeque Coronae Ungarice, superbum, elegantia operis, nulli sacro Reliquiario secundum, Romana industria elaboratum, mihi ad ecclesiam nostram Zagrabiensem deferendum, ad manus, ingenti animi alacritate consignavit. in cuius illustrissimi ornamenti basi, eiusmodi pietatis argumentum incisum est perlegere, quod eque erga sanctissimum Regem, eminentissimae tanti Cardinalis pietatis, ut erga gentem nostram paterni affectus argumentum (...). ${ }^{3}$ Barberini's donation and Tomko Mrnavić's involvement in it were reported by a number of later commentators from Farlati onwards (DANIELE FARLATI, Illyrici sacri tomus quintus, Venezia, 1775, p. 562). Nevertheless, art historians who highlighted the artistic quality of the reliquary made no mention whatsoever of Mrnavić (A. HORVAT, Između gotike i baroka - umjetnost kontinentalnog dijela Hrvatske od oko 1500. do oko 1700., Zagreb, 1975, pp. 162, 165-166, 168; V. MARKOVIĆ, entry 82, in The Croats - christianity, culture, art: exhibition catalogue, V. MARKOVIĆ,
} 


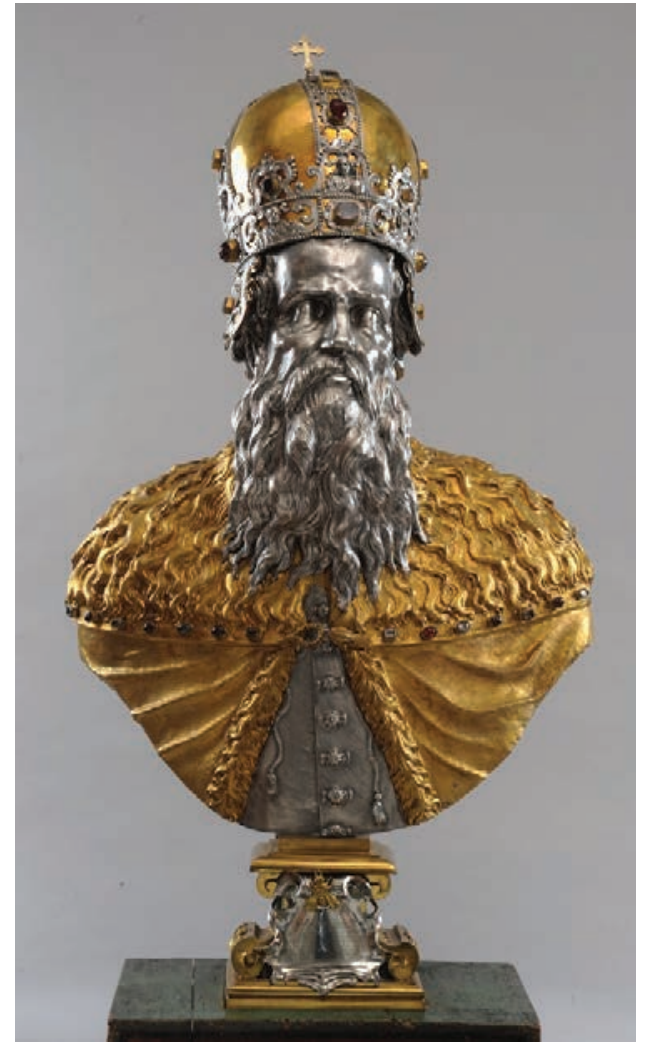

Fig. 1. Francesco Spagna, Reliquary Bust of St Stephen the King, 1635, silver, copper, gilt, precious stones; height $113 \mathrm{~cm}$; Zagreb Cathedral's Treasury (photo: Attila Mudrák)

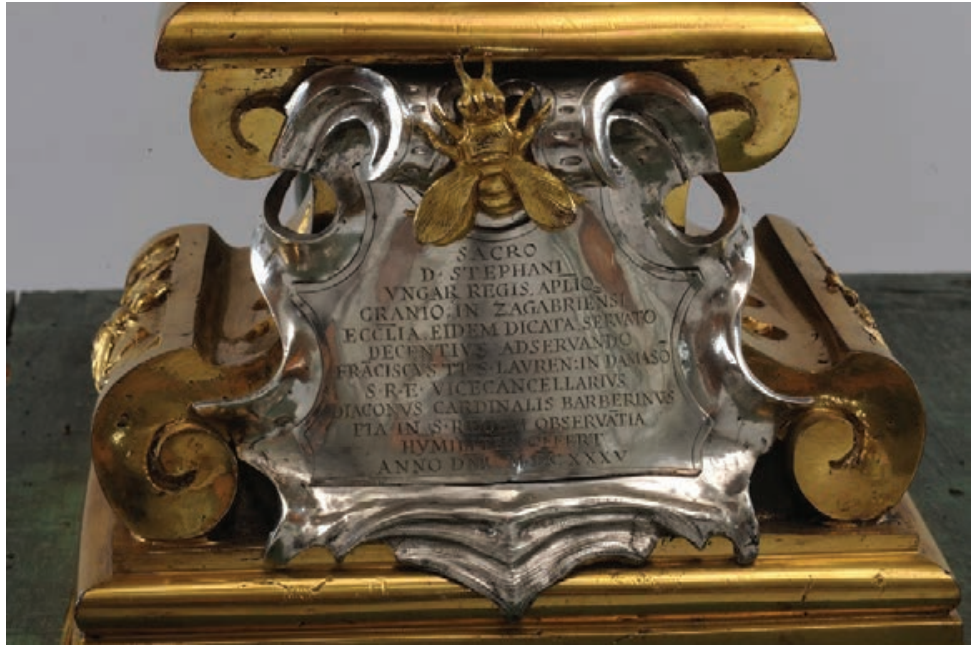

Fig. 2. Detail of fig. 1, plinth, model attributed here to Gian Lorenzo Bernini (photo: Attila Mudrák)

of the best, as well as one of the largest. In 2010 I examined it more closely, with the following conclusions. ${ }^{4}$ The plinth with its cartouche is a superb piece of the Roman Baroque design (fig. 2), resembling the plinth of Bernini's marble bust of Urban VIII's uncle Francesco Barberini (National Gallery of Art, Washington). The chest and shoulders, on the other hand, display inferior sculpting skills, which appear to have been designed by a silversmith. However, it is the saint's head (fig. 3), „pulsating with an all-pervasive intensity, emanating a controlled pathos, as well as a kind of low-key ecstasy", which reveals modelling by a distinguished sculptor: I attri-

A. BADURINA (eds.), Zagreb, 1999, pp. 506-507). Recently, detailed studies of the reliquary and the context of its commission were provided by D. PREMERL, Zagreb Cathedral's Reliquary bust of Saint Stephen the King: the Context of its Commission and its Attribution, in Radovi Instituta za povijest umjetnosti 34, Zagreb, 2010, pp. 101-112; D. ŠOUREK, Ad imitationem angelicae, apostolicaeque coronae Ungaricae. Prilog ikonografiji krune na prikazima svetih kraljeva $u$ zagrebačkoj katedrali, in Peristil 54, Zagreb, 2011, pp. 177-186; D. PREMERL, "Szent István király zágrábi ereklyetartó mellszobra", in István, a szent király: exhibition catalogue, KERNY T., SMOHAY, A. (eds.), Székesfehérvár, 2013, pp. 47$63,293,502$ (In the chapter of the Hungarian catalogue I will include new documents concerning Francesco Spagna published in this article; however, the said chapter will discuss the Zagreb cathedral reliquary in more detail). See also: I. KUKULJEVIĆ SAKCINSKI, Prvostolna crkva zagrebačka, Zagreb, 1856, pp. 50-51; IPOLYI A., Magyar ereklyék, in Archaeologiai közlemények 3, Pest, 1863, p. 103; I. K. TKALČIĆ, Prvostolna crkva zagrebačka, Zagreb, 1880; GERECZE P., Magyarország müemlékei, vol. II, Budapest, 1906, p. 1116; LJ. IVANČAN, Inventar Metropolitanske crkve Zagrebačke (manuscript, Nadbiskupski arhiv u Zagrebu), Zagreb, 1915., pp. 38-39; J. BRAUN, Die Reliquiare des Christlichen Kultes und ihre Entwicklung, Freiburg im Breisgau, 1940, p. 422; GALLA, F., Marnavics Tomkó János Boszniai Püspök Magyar vonatkozásai, Budapest, 1940 (Croatian review of that book was published by Z.T. in Časopis za hrvatsku povijest I/4, Zagreb, 1943, pp. 372-374); Popis Riznice zagrebačke katedrale (Here is a detailed description, provided by Ivan Bach. The list was compiled by the Heritage Preservation Institute in Zagreb in 1951), manuscript, Ministry of Culture of the Republic of Croatia, br. 114 (165), pp. 73-76; A. IVANDIJA, Inventar Riznice zagrebačke katedrale, part I/vol. I, (typewritten, Nadbiskupski arhiv u Zagrebu), Zagreb, 1986, no. M 165, pp. 135-137; I. LENTIĆ, entry 59 M, in Riznica zagrebačke katedrale: exhibition catalogue, Z. MUNK (ed.), Zagreb, [s.a. 1987], p. 191; Id., entry 25 Ri, in Tisuću godina hrvatske skulpture: exhibition catalogue, I. FISKOVIĆ (ed.), Zagreb, 1991, p. 119; Id., entry 89, in Sveti trag - Devetsto godina zagrebačke nadbiskupije 1094-1994.: exhibition catalogue, T. LUKŠIĆ, I. REBERSKI (eds.), Zagreb, 1994, p. 401; U. PIERETH, entry 1.10, in Bayern - Ungarn. Tausend Jahre: exhibition catalogue, W. JAHN, C. LANKES, W. PETZ, E. BROCKHOFF (eds.), Regensburg, 2001, pp. 40-42; BENE S., „A Szilveszter-bulla nyomában (Pázmány Péter és a Szent István-hagyomány 17. századi fordulópontja)“, in "Hol vagy István király?" A Szent István-hagyomány évszázadai, BENE, S. (ed.), Budapest, 2006, pp. 89-124; M. PELC, Povijest umjetnosti u Hrvatskoj, Zagreb, 2012, p.337.

${ }^{4}$ For details see D. PREMERL, Zagreb Cathedral's Reliquary bust of Saint Stephen the King, op. cit. 
buted the cast's unknown terracotta model to Alessandro Algardi. Furthermore, I assumed that Barberini had commissioned the reliquary from a silversmith: the silversmith in his turn would have commissioned a terracotta model of the saint's head from Algardi or would have simply used Algardi's model already in his possession; also, I presumed that the silversmith had cast the plinth using the Berniniesque model he had possessed. As for the chest, I supposed that he had modelled it himself in order to avoid additional expenses. In my 2010 article I also interpreted the context of the commission, shedding light on the Croatian ecclesiastic Ivan Tomko Mrnavić as the co-commissioner of the reliquary. Tomko Mrnavić spent much of his life in Rome, working for the Congregatio de Propaganda Fide and the Holy See. He was close to the Barberini as suggest his books published under their aegis. I interpreted Francesco Barberini's donation as a sign of gratitude to his longtime loyal confidant and advisor on Illyrian issues, yet all the more so as a sign of respect and encouragement to the diocese of Zagreb straddling the outer border of the Pope's spiritual rule and influence. Both Barberini and Tomko Mrnavić were well aware that the Catholic Reform consisted of faith-inciting art donations as well as those that might have been instrumental for the construction

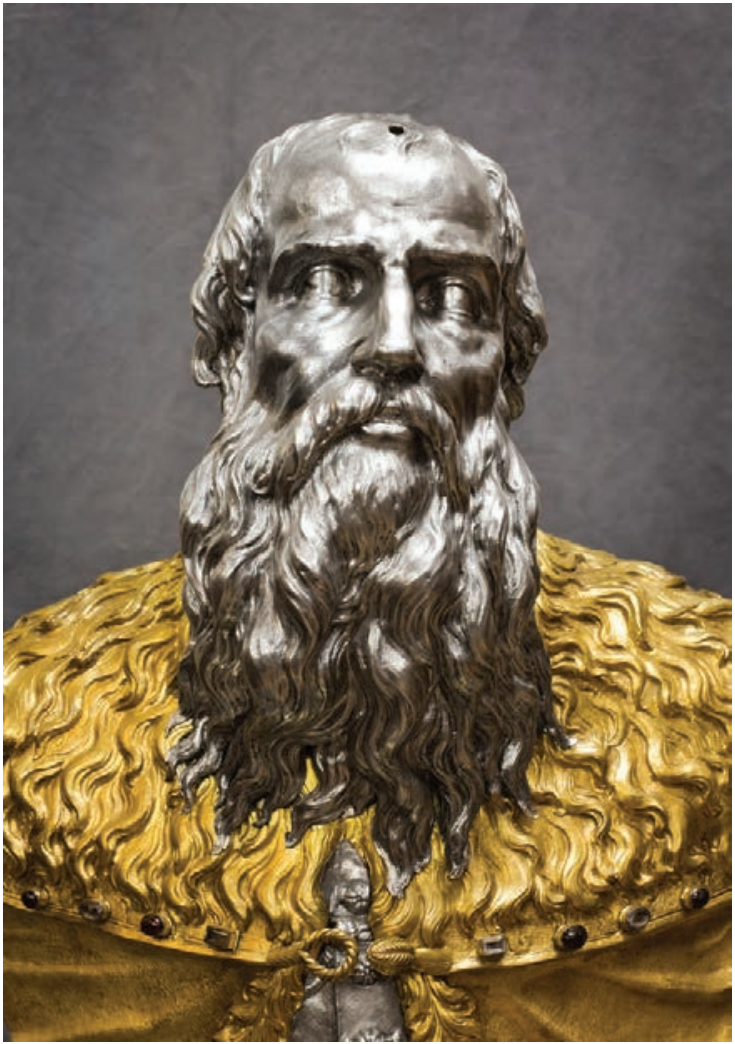

Fig. 3. Detail of fig. 1, head, model attributed to Alessandro Algardi (photo: Paolo Mofardin; Institute of Art History, Zagreb) of the historical Christian identity of a local Church.

In 2011 Danko Šourek examined the reliquary's crown and its iconography, with the following conclusions. ${ }^{5}$ The crown might have also been made in Rome, and not in Central Europe (as was held by previous researchers). The crown's shape derives from the shape of the cap of the Roman prefect, as visible, for example, on the bust of Taddeo Barberini (Museo di Roma) and on his other portraits, as well as from the Holy Crown's description in Péter Révay's book De sacrae Coronae Regni Hungariae (Augsburg, 1613). The design of the Zagreb reliquary's crown had become a model for some subsequent representations of crowns of the Hungarian-Croatian kings in the Zagreb bishopric. Finally, Šourek revealed further details related to the Zagreb cult of St Stephen and its symbolic use in legitimizing the Catholic orthodoxy of the Zagreb bishopric (associated to the successful spread of Protestantism in Hungary).

It is also worth noting that Sándor Bene (2006) interpreted the donation of the Zagreb reliquary against the backdrop of Tomko Mrnavić's successful role in the campaign of inclusion of St Stephen in the Roman calendar. ${ }^{6}$

\footnotetext{
${ }^{5}$ For details see D. ŠOUREK, op. cit.

${ }^{6}$ Bene argues that Tomko Mrnavić was instrumental in the reconciliation between the Hungarian Church and the Hungarian Habsburg King on one side and the Holy See on the other. The issue at stake was the Hungarian king's traditional right to nominate bishops (and to control ecclesiastical affairs), which turned out to be against Tridentine guidelines. This privilege was allegedly given to Stephen by the pope. The situation got worse as the Holy See began sending missionaries to Bosnia without consulting the Hungarian king and the Hungarian church hierarchy. The dispute caused the pontiff's refusal to include St Stephen in the Roman calendar. However, the situation suddenly changed in 1631, and it seems that Tomko's influence led to the solution that left all parties satisfied: the Hungarian king kept his right, St Stephen was included in the calendar, and Tomko became the bishop of Bosnia. See BENE S., op. cit.
} 
In the present article, however, new documents from the Biblioteca Apostolica Vaticana will reveal that Francesco Barberini commissioned the Zagreb reliquary from the silversmith Francesco Spagna. I am deeply grateful to Jennifer Montagu who found, transcribed, and kindly and instructively handed me down those documents.

In Francesco Barberini's Giornale, within the list of payments made to Francesco Spagna Argentiero for various objects made of silver, gold and other materials in the period between November 1634 and June 1635, figures a payment "per una testa di Argento di Santo Stefano Re di Ungheria con il regnio in testa tutto cisellato di basso rilievo con li 12 apostoli à torno guarnito con div.se pietre e fogliami con il busto di Rame dorato con il petto d'Argento, e la basa di Rame dorata di peso in tutto di lb 13 o[ncie] 3 donato à Mons.re Zonchi Vescovo di Porsena". ${ }^{7}$ This entry clearly refers to the Zagreb reliquary. As for "Monsignore Zonchi vescovo di Porsena", in my opinion it is either misspelled or misread. I think that it should be read as "Monsignore Tomcho Vescovo di Bossina", i.e. Tomko the bishop of Bosnia.

Another, more thorough document about the Zagreb reliquary is to be found in Francesco Barberini's Giustificazioni. It is the list of expenses for the reliquary that Francesco Spagna issued to the cardinal-nephew. In the transcription of the document that follows the price requested by Spagna for each item is transcribed faithfully following the original, i.e. at the end of each entry. On the other hand, the prices that Barberini actually agreed on, originally noted on the left margin of the page, are here transcribed in brackets following the requested prices. The document reads:

"E adi 12 Marzo 1635 per aver fatto una testa di Argento di S. Stefeno Re di Ungheria con il Regno in testa tutto cisellato di basso Rilievo con li dodici Apostoli attorno e guarnito Con diverse pietre e fogliami con il busto di Rame dorato Col Petto di Argento e la basa di Rame dorata con lignudo [?] del Regno peso largento della testa con la guarnitione del Regno peso -- $1 b .13$ o.- d.3 si valuta la lb senza il Calo s.11 b.20 la lb per essere argento di piastre fiorestere ---s.145;75 (145.75) [A note on the margin reads: Donata a Mo. Zonchi Vesco di Porssena.]

E per il Calo di detto Argento b.12 per il lb che cosi e saldo [?] ---s.6:57 (5.80[?])

E piu peso largento della Cortella della Basa e il petto di argento peso -- lb.- $0.10 \mathrm{~d} .9$ si valuta la lb. per essere Argento di Carlino col Calo s.11 b.10 la lb. ---s.9:60 (9.60)

Somma la Rietro scritta facciata e segue ---s.214;82 (208.95)

E per il Rame del busto del Regno e della basa di detta testa peso -- $1 b .56$ si valuta la lb. b.30 --s.16:80 (15.50)

E per loro che ando a indorare il busto e la Coronna [?] eb [?] Testa con la busta pagati giuli 161/2 luno in tutto ---s.75:90 (75)

E per aver fatto li Castoni a n.o 25 pietre diverse di Rame indorati pagati b.20 l'uno ---s.5 (3.75)

E per aver fatto legare quatro granuti [?] grosse a frecette [faccette?] che andarano nel Regno pagati b.40 luno ---1:60 (1.20)

E per il ferro fatto fare dentro a detta testa pagato ---s.3:- (2)

E per la fattura di detta testa ---89---s.300 (200)". ${ }^{8}$

As we have seen, the only price that was significantly reduced was the price of execution: Spagna requested 300 scudi while Barberini agreed on 200. In total, Spagna valued the material and the execution of the reliquary at 418,47 scudi, which Barberini reduced to 312,85 scudi. It is obvious that Spagna's list of expenses is not entirely precise: he stipulates that he made twelve reliefs of apostles, whereas the crown is decorated by eight figures. However, the document in question confirms

\footnotetext{
${ }^{7}$ Biblioteca Apostolica Vaticana. Mss., Archivio Barberini. Computisteria, b. 68. Fran.o Barberini, Giornale, 134/140. A spese di Donativi...Giug[no] pross[imo passa] to cioe (...). Document previously published in A. GONZÁLEZ-PALACIOS, Concerning Furniture: Roman Documents and Inventories, Part I, c. 1600-1720, in Furniture History 66, London, 2010, p. 32.

${ }^{8}$ Biblioteca Apostolica Vaticana. Mss., Archivio Barberini. Cardinal Francesco Barberini, Giustificazioni vol. 23a 1635, 2342, Conti dello Argentiero 1635 (...) Francesco Spagna (...).
} 
Šourek's claims for the Roman provenance of the crown. On the other hand, it reveals nothing about the possible authors of the models for the head and the plinth. While in my 2010 article I wrote that the plinth resembles the plinth by Bernini, now I would say that it might well be cast after a model by Bernini.' Spagna executed Bernini's designs so it would have been possible that he possessed his models. That may lead us to the conclusion that the head might also have been cast after a model by Bernini or somebody from his circle. However, to my eye and knowledge, St Stephen's head simply does not display the style of Bernini or somebody from his circle. Instead, it shows stylistic features of Algardi. As the documents do not mention that Spagna sub-contracted any sculptor for the plinth and the head, we may well assume that he had used the models he had already possessed.

Francesco Spagna $(1602-1640)^{10}$ regularly worked for the Barberini; since 1627 or 1628 he is mentioned as papal silversmith and jeweler. Art historiography most often refers to his 1636 reliquary of St Helen, made after a drawing by Bernini and commissioned by Francesco Barberini as the gift to the Queen of England (not preserved), ${ }^{11}$ as well as to the 1635 Golden Rose, Urban VIII's gift to Maria Anna, wife of Maximilian of Bavaria (fig. 4)..$^{12}$ In addition, the following works by Spagna commissioned by the Barberini are also documented: a silver ornament for the church Madonna degli Angeli in Assisi (1627), ${ }^{13}$ a golden necklace for Guido Reni (1628), ${ }^{14}$ the gilding of the 1633 famous and costly

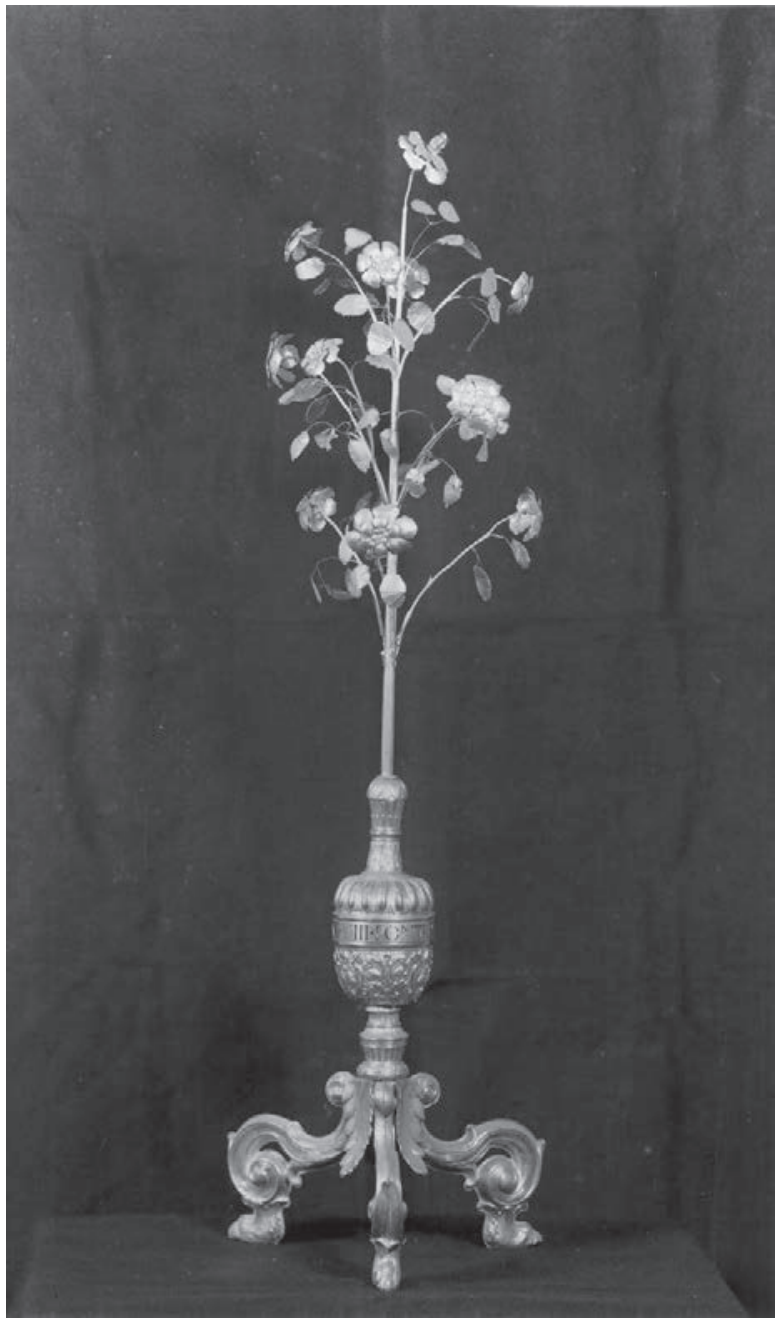

Fig. 4. Francesco Spagna, Golden Rose, 1635, gold, sapphire, height $87 \mathrm{~cm}$ (Schatzkammer der Residenz München; Bayerische Verwaltung der staatlichen Schlösser, Gärten und Seen)

\footnotetext{
${ }^{9}$ For Bernini's „brilliantly conceived cartouches" and plinths see J. MONTAGU, Busts and their bases, in Sculpture journal 20/2, Liverpool, 2011, p. 157.

${ }^{10}$ Francesco Spagna took over his deceased father Pietro's silversmith workshop in Via del Pellegrino in 1627 (V. GAZZANIGA, "La vita e le opere di Fantino Taglietti argentiere e altri protagonisti della produzione argentaria a Roma tra Cinquecento e Seicento", in A. DI CASTRO, P. PECCOLO, V. GAZZANIGA, Marmorari e argentieri a Roma e nel Lazio tra Cinquecento e Seicento, Roma, 1994, p. 233). Lorizzo established that Francesco Spagna died in 1640, and not in 1642 as was held by previous researchers (L. LORIZZO, La collezione del cardinale Ascanio Filomarino, Napoli, 2006, 52 n. 50).

${ }^{11}$ J. MONTAGU, Roman Baroque Sculpture - The Industry of Art, New Haven-London, 1989, p. 116; M. ARONBERG LAVIN, Seventeenth-Century Barberini Documents and Inventories of Art, New York, 1975, p. 6.

${ }^{12}$ It was identified as Spagna's work in J. MONTAGU, Gold, Silver and Bronze-Metal Sculpture of the Roman Baroque, New Haven-London, 1996, p. 17, 217 n. 96; See also Schatzkammer der Residenz München, H. THOMA, H. BRUNNER (Hrsg. von), München, 1964, p. 112-113; Schatzkammer der Residenz München, H. BRUNNER (Hrsg. von), München, 1970, p. 127.

13 "un hornamento d'argento che doveva fare per serv.o della Chiesa della Madon'a dell'Angeli d'Assisi" (M. ARONBERG LAVIN, op. cit., p. 40).

14 "una collana d'oro donata à Guido Reni pittore" (Ibidem, p. 30).
} 
apparato for Quarant'Ore designed by Pietro da Cortona for the Roman church of San Lorenzo in Damaso, ${ }^{15}$ the reliquary for the Roman church of SS. Stimmate di S. Francesco (1633), ${ }^{16}$ "un ornamento ai due sportelli d'argento (...) fatti di piastra di basso rilievo", commissioned from Spagna by Bernini for the confessio of the Vatican basilica (1633), ${ }^{17}$ the sumptuous reliquary of St Martina (1635), made to be shipped with other works of art to England by George Conn..$^{18}$ Also, Barberini's Giornale lists, in addition to the Zagreb reliquary given to Tomko Mrnavić, many other sumptuous objects made by Spagna: reliquaries, silver frames (one destined for a painting by Pietro da Cortona), little boxes, vases with flowers. Some of those objects were diplomatic gifts as we read that they were presented to the Queen of England, the King of Spain, the Spanish and the Savoyard ambassador, the bishop of Catania and a French abbot and so on. ${ }^{19}$ Spagna also worked for Francesco Barberini's maestro di camera Ascanio Filomarino, a prominent collector and patron of artists such as Poussin, Caravaggio, Vouet, Valentin, Duquesnoy and so on. Filomarino paid Spagna for "l'indoradura d'un Canestro d'Argento, un Cannone d'Argento et 4 Scatolini da tener medicamenti" (1630), and for a chalice with a paten (1639)..$^{20}$ Spagna's catalogue is without any doubt much bigger, but at the moment there has been no occasion to examine it in depth.

Finally, it is interesting to note that the 1640 inventory of Francesco Spagna's possessions mentions, for example, painted portraits of himself, portraits of his father and cardinals Francesco and Antonio Barberini, as well as cameos and medals (some of them inherited by Francesco Barberini after Spagna's death). Moreover, Spagna's inventory makes mention of "una testa di San Francesco di Paola d'argento di rilievo con un poco di busto di rame dorato con la sua basa d'ebano."21 It might well have been that this, or indeed some other old saint's head had served as the model for our St Stephen. However, the current state of knowledge on Francesco Spagna's Roman workshop and the division of labour in it remains very scarce. ${ }^{*}$

\footnotetext{
${ }^{15}$ J. M. MERZ, Pietro da Cortona and Roman Baroque Architecture, New Haven-London, 2008, pp. 43, 293 n. 3.

${ }^{16}$ Roma (Touring Club Italiano), A. FERRARI-BRAVO (a cura di), Milano 2002, p. 210.

${ }^{17}$ M. A. NOCCO, Ritrovato il primo contratto per il baldacchino di San Pietro, in L'Osservatore Romano, 9 gennaio 2010, cited from http://www.vatican.va/news_services/or/or_quo/cultura/2010/006q04a1.html.

18 "Reliquario (...) di S. Martina V.M. (...) hauto da Francesco Spagna pagato (...)" (M. ARONBERG LAVIN, op. cit., p. 11).

${ }^{19}$ A. GONZÁLEZ-PALACIOS, op. cit., p. 4, 31-35, 37-39, 112.

${ }^{20}$ L. LORIZZO, Cardinal Ascanio Filomarino's Purchases of Works of Art in Rome: Poussin, Caravaggio, Vouet and Valentin, in The Burlington Magazine CXLIII/1180, London, July 2001, p. 410; The same is repeated in L. LORIZZO, La collezione del cardinale Ascanio Filomarino, Napoli, 2006.

${ }^{21}$ I am most grateful to Jennifer Montagu who kindly e-mailed me unpublished excerpts from Francesco Spagna's inventory. Archivio di Stato di Roma, Not. Trib. A.C., Fonthia, vol. 3173, f. 912v (ff.868-877v, 880-954).

"This work has been fully supported by Croatian Science Foundation's funding of the project 6827 Visual Arts and Communication of Power in the Early Modern Period (1450-1800): Historical Croatian Regions at the Crossroads of Central Europe and the Mediterranean.
} 


\section{DJELO PAPINSKOG SREBRNARA FRANCESCA SPAGNE ZA ZAGREBAČKU KATEDRALU: RELIKVIJAR-POPRSJE SV. STJEPANA KRALA}

U članku se objavljuju dva nepoznata dokumenta iz poslovnih knjiga Giornale i Giustificazioni kardinala Francesca Barberinija (Biblioteca Apostolica Vaticana), u kojima se identificira relikvijar sv. Stjepana Kralja (1635.) što ga je kardinal, na poticaj Ivana Tomka Mrnavića, poklonio zagrebačkoj katedrali. Dokumenti otkrivaju da je kardinal Barberini relikvijar naručio kod papinskog srebrnara Francesca Spagne.

Novopronađeni dokumenti potvrđuju Šourekovu pretpostavku (2011.) da je kruna relikvijara također nastala u Rimu (do tada se smatralo da je srednjoeuropski rad). Također, dokumenti potvrđuju Premerlovu pretpostavku (2010.) da je relikvijar-poprsje izradio srebrnar. Dokumenti, međutim, ne otkrivaju od koga je Spagna naručio model postolja i glave, koji su vrsna djela rimskog kiparskog baroknog oblikovanja. U članku se pretpostavlja da je postolje zagrebačkog relikvijara izliveno prema modelu Gian Lorenza Berninija, te se zadržava ranija atribucija terakotnog modela glave rimskom kiparu Alessandru Algardiju.

Francesco Spagna (1602.-1640.) je redovito radio za Barberinije, bio je papin srebrnar i izrađivač nakita. U historiografiji se najčešće spominje njegov relikvijar sv. Helene (1636.), izrađen prema Berninijevom crtežu, dar Francesca Barberinija engleskoj kraljici (nije sačuvan), te Zlatna ruža (1635.), dar Urbana VIII. Mariji Ani, ženi Maksimilijana Bavarskog (Schatzkammer der Residenz München). U članku se navodi i izbor ostalih Spagninih djela.

Ključne riječi: Francesco Spagna, relikvijar-poprsje sv. Stjepana Kralja, zagrebačka katedrala, Francesco Barberini, Ivan Tomko Mrnavić, Alessandro Algardi, Gian Lorenzo Bernini 